\title{
RADIONUCLIDE ASSESSMENT OF CARDIOPROTECTIVE EFFICIENCY OF HYPOXIC PRECONDITIONING
}

\author{
Vesnina Zh.V.' , Krivonogov N.G.' , Arsenjeva Yu.A. ', \\ Nesterov E.A.2, Lishmanov Yu.B.'
}

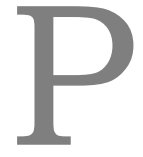

urpose. Using radiocardiopulmonography to evaluate the cardioprotective effectiveness of hypoxic preconditioning (HP) during myocardial revascularization under extracorporeal circulation (EC).

Material and methods. A total of 63 patients (mean age of $52.8 \pm 1.4$ years) who underwent coronary bypass surgery (CABG) under EC condition were examined. All patients had chronic heart failure of NYHA class I-III. Patients were randomized into 2 groups: study group comprised 33 patients who received HP during CABG; comparison group comprised 30 patients. Patients of both groups were comparable in regard to clinical and intraoperative data. The preconditioning was performed as a single-cycle 10-minute hypoxemia session followed by 5 -min period of reoxygenation before global ischemia. Radiocardiopulmonography with $99 \mathrm{mTc}$-pertechnetate was performed before and 6-8 days after surgery with the calculation of the parameters of cardiopulmonary hemodynamics.

Results. In the examined patients before CABG we observed a decrease in the mean values of the cardiac output (MO), cardiac index (HI), stroke index (SI) and circulation efficiency ratio (CER) as a consequence of a decrease in the pumping function of the heart, as well as an increase in the pulmonary circulation time (TPUL) due to both arterial and venous components, which indicated the development of pulmonary hypertension and venous congestion of the left heart.

In the postoperative period, positive statistically significant change in most parameters of cardiopulmonary hemodynamics occurred as a result of successful myocardial revascularization in patients of both groups: the values of MO, SI, CER increased, and halfemptying period of the left and right ventricles and the value of TPUL decreased. It should be noted that the positive dynamics of these parameters was statistically more pronounced in the patients of the study group. Also, in contrast to the comparison group, the arterial component of circulation in the lungs and the half-emptying period of the right ventricle significantly decreased in patients with HP, which indicated a reduction in pulmonary hypertension and a regression of right ventricular failure.

On day 2 after surgery blood levels of creatine-kinase (CK) and CK-MB were increased in patients of both groups. The mean level of CK-MB was significantly higher (by $33 \%)$ in the comparison group relative to the study group $(\mathrm{p}=0.046825)$, and the relative index $(\mathrm{RI}=\mathrm{CK}-\mathrm{MB} / \mathrm{CK} \times 100)$ in the study group did not exceed $6 \%$. This data suggested that HP increased the tolerance of the heart to the effects of "ischemia-reperfusion".

Conclusion. Hypoxic preconditioning exerted cardioprotective activity in patients undergoing open-heart surgery under EC.

Keywords: coronary artery bypass grafting, hypoxic preconditioning, cardioprotective effectiveness, radiocardiopulmonography

Corresponding author: Vesnina Zh.V., e-mail: vesninazh@gmail.com

For citation: Vesnina Zh.V., Krivonogov N.G., Arsenjeva Yu.A., Nesterov E.A., Lishmanov Yu.B. Radionuclide assessment of cardioprotective efficiency of hypoxic preconditioning. REJR 2019; 9(3):65-72. DOI:10.21569/2222-7415-2019-9-3-65-72.
Статья получена:
03.07.19
Статья принята:
22.08.19

1 - Cardiology Research Institute, Tomsk Nationale Research Medical Centre, Russian Academy of Sciences.

2 - Tomsk National Research Polytechnic University. Tomsk, Russia. 


\section{РААИОНУКАИАНАЯ ОЦЕНКА КАРАИОПРОТЕКТИВНОЙ ЭФФЕКТИВНОСТИ ГИПОКСИЧЕСКОЙ АААПТАЦИИ}

\author{
Веснина Ж.Т. ', Кривоногов Н.Г. ', Арсеньева Ю.А. ', \\ Нестеров Е.А. ${ }^{2}$, Аишманов Ю.В.1
}

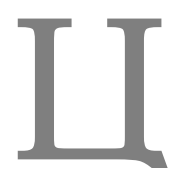

ель. Использование радиокардиопульмонографии для оценки кардиопротективной эфффективности гипоксического прекондиционирования (НР) при реваскуляризации миокарда при экстракорпоральном кровообращении (ЭК).

Материалы и методы. Обследовано 63 пациента (средний возраст 52,8 \pm 1,4 года), которым была выполнена операция коронарного шунтирования (CABG) в усмовиях ЭК. У всех пациентов была хроническая сердечная недостаточность I-III класса по NYHA. Пациенты были рандомизированы на 2 группы: в основную группу вошли 33 пациента, которые получали НР во время АКШ; группу сравнения составили 30 пациентов. Пациенты обеих групп были сопоставимы по клиническим и интраоперационным данным. Предварительное кондиционирование проводимось в виде 10-минутного сеанса гипоксемии с одним циклом с последующим 5-минутным периодом повторной оксигенации перед глобальной ишемией. Радиокардиопульмонография с $99 \mathrm{mTc}-$ пертехнетатом проводимась до и через 6-8 дней после операции с расчетом параметров сердечно-легочной гемодинамики.

Результаты. У обследованных пациентов до CABG мы наблюдали снижение средних значений сердечного выброса (МО), сердечного индекса (НI), ударного индекса (SI) и коэффициента эффективности кровообращения (CER) как следствие снижения насосной функции сердца, а также увеличение времени мегочной циркуляции (TPUL) из-за артериальных и венозных компонентов, что свидетельствует о развитии мегочной гипертонии и венозной гиперемии цевых отдемов сердца.

В послеоперационном периоде положительное статистически значимое изменение большинства параметров сердечно-легочной гемодинамики произошло в результате успешной реваскуляризации миокарда у пациентов обеих групп: значения МО, СИ, CER увеличились, а период полувыведения в области мевого и правого желудочков и значение TPUL уменьшилось. Следует отметить, что положительная динамика этих показателей быма статистически более выраженной у пациентов основной группы. Кроме того, в отмичие от группы сравнения, артериальный компонент кровообращения в мегких и период полувыведения правого желудочка значительно снизился у пациентов с НР, что указывало на снижение цегочной гипертензии и регрессию правожелудочковой недостаточности.

На 2-й день после операции у пациентов обеих групп были повышены уровни креатинкиназы (CK) и CK-MB в крови. Средний уровень CK-MB был значительно выше (на 33\%) в группе сравнения по сравнению с основной группой (p=0,046825), а относительный индекс (RI = CK-MB / CK x 100) в основной группе не превышал 6\%. Эти данные свидетельствуют о том, что НР повышает толерантность сердца к эффектам "ишемии-реперфузии".

Выводы. Гипоксическое прекондиционирование оказывало кардиопротекторную активность у пациентов, перенесших операцию на открытом сердце при ЭК.

Ключевые слова: шунтирование коронарных артерий, гипоксическое прекондиционирование, кардиопротективная эффективность, радиокардиопульмонография.

Контактный автор: Веснина Ж.В., e-mail: vesninazh@gmail.com

Для иитирования: Веснина Ж.Т., Кривоногов Н.Г., Арсеньева Ю.А., Нестеров Е.А., Аишманов Ю.В. Радионуклидная оценка кардиопротективной эфррективности гипоксической адаптаиии. REJR 2019; 9(3):65-72. DOI:10.21569/2222-74152019-9-3-65-72.

Received: $\quad$ 03.07.19 Accepted: $\quad 22.08 .19$
1 - Кардиологический научно-

исследовательский институт, Томский национальный исследовательский медицинский центр, Российская Академия Наук.

2 - Томский национальный исследовательский политехнический университет. Томск, Россия. 


\section{I}

\section{ntroduction.}

One of the most effective methods of treatment of coronary heart disease is coronary bypass surgery (CABG) with the use of exstracorporeal circulation (EC). Unfortunately, in some cases, EC becomes the cause of adverse physiological disorders, leading to ischemia or infarct of the internal organs $[1,2]$.

The high intensity of metabolism in the brain, and the heart and, accordingly, the high demand of these organs for oxygen is well known [3]. These features determine the sensitivity of these organs to ischemia-reperfusion (IR) injury. Neurons die when the duration of ischemia is more than 2 min [4]; irreversible injury of cardiomyocytes occurs when the duration of IR exceeds $10 \mathrm{~min}$ [5]. Such sensitivity to hypoxia predetermines the onset of damage to the heart and the brain during surgical interventions with EC $[6,7]$.

Thus, the problem of providing cardioprotection during open heart surgery under EC conditions remains relevant. In our opinion, hypoxic preconditioning is promising for protection of the myocardium from the adverse effects of systemic inflammatory response and ischemia in cardiac surgery.

Hypoxic preconditioning (HP) means an increase in the tolerance of organs and tissues after severe long-term hypoxia (ischemia) by means preliminary modeling of one long $(2.5-3 \mathrm{~h})$ or several short sessions of hypoxia (2-10 $\mathrm{min})$ and reoxygenation (2-10 $\mathrm{min})$. The term "hypoxic preconditioning" was first proposed in 1992 by researchers from the group of Professor H.F.Downey from Texas [9]. Cardioprotective effect of HP has been studied widely. The pioneering works focusing on this problem showed that preconditioning promotes an increase of tolerance of the heart to ischemia and reperfusion $[9,10]$. The cardioprotective effect of HP is judged by the ratio between infarct size and the area at risk $[11,12]$. The area at risk corresponds to a hypoperfusion zone in the area supplied by the occluded coronary artery. It was established that after the HP 3 times decreases the index of "area of infarction/area of risk" compared with control [9]. Hypoxic preconditioning in vivo not only helps to limit the infarct zone, but also prevents the appearance of reperfusion contractile myocardial dysfunction $[10,12,13]$.

Delayed HP, in which an increase in the resistance of organs and tissues to hypoxia is observed 16-24 hours after hypoxia-reoxygenation is most studied [11-13].

Early HP, when it is possible to achieve an increase in tolerance to ischemia immediately after exposure to hypoxia and reoxygenation is less investigated [9, 10, 14]. Both early and delayed variants of $\mathrm{HP}$ are associated with infarct-limiting effect. At the same time, a more pronounced increase in heart tolerance to the action of IR can be achieved with early HP [15].

It should be noted that the above mentioned works were performed on experimental animals. Potencial capabilities of clinical application of HP remain virtually unexplored. Only a few studies concerning the use of preconditioning in clinical practice are available to date [16, 17]. Moreover, clinical studies assessing the cardioprotective effectiveness of preconditioning did not use highly informative methods of nuclear medicine. In particular, radionuclide cardiopulmonography, which is based on dynamic registration of the passage of the radiopharmaceutical bolus through the cavities of the heart and the lungs, allowing to acquire objective information about these central hemodynamic parameters such as stroke and minute volumes, and cardiac and stroke indices [18]. Obtaining these values may allow integrated assessment of the central hemodynamic parameters. In addition, radiocardiopulmonography is a unique method of non-invasive evaluation of pulmonary circulation (PC), allowing to estimate a number of speed indicators of blood circulation in the lungs [19].

Thus, the purpose of this investigation was to perform the radionuclide assessment of cardioprotective efficacy of HP during open heart surgery with extracorporeal blood circulation.

\section{Material and methods.}

The study included 63 patients with coronary artery disease of angina functional classes 2-4 complicated by chronic heart failure ( $\mathrm{CHF})$ of NYHA classes I-III (average age of $57.20 \pm 1.49$ years) who underwent CABG with EC. Of these patients, 56 suffered one or more acute myocardial infarction with the formation of post-infarction cardiosclerosis. All patients were divided into 2 groups: 33 persons underwent HP during CABG (study group), comparison group comprised 30 patients. Patients of both groups were comparable in regard to age, clinical characteristics and intraoperative parameters (Table 1).

Hypoxic preconditioning was performed as follows: after the beginning of EC and the cessation of artificial lung ventilation before aorta cross-clamping, a 10-minute hypoxemia cycle is performed by supplying a gaseous mix to the oxygenator with a reduced oxygen content to $21-22 \%$, followed by a 5-minute period of reoxygenation before global ischemia. This gaseous mix provides reduction of $\mathrm{paO} 2$ to $30-35 \mathrm{~mm} \mathrm{Hg}$ and $\mathrm{SaO} 2$ to $55-65 \%$. According to cerebral oximetry (Oximeter INVOS Somanetics), rSO2 decreased to 52-59\%. These parameters could not be reduced below the critical levels: the saturation of arterial blood of $50 \%$, and the corresponding oxygen tension of 27 $\mathrm{mm} \mathrm{Hg}$ in arterial blood.

Patients of both groups underwent a radiocardiopulmonography (RCPG) with 99mTcpertechnetate. The method is based on a sequen 
Table №1. Clinical and intraoperative data of patients enrolled in the study.

\begin{tabular}{|c|c|c|c|c|}
\hline \multirow[t]{2}{*}{ Variables } & \multicolumn{2}{|c|}{ Study group } & \multicolumn{2}{|c|}{ Comparison group } \\
\hline & $\mathrm{n}=33$, abs. & $\%$ & $\mathrm{n}=30$, abs. & $\%$ \\
\hline Age, years* & \multicolumn{2}{|c|}{$56.24 \pm 1.17$} & \multicolumn{2}{|c|}{$58.16 \pm 1.81$} \\
\hline CHF (NYHA): I & 3 & 9.1 & 2 & 6.7 \\
\hline II & 23 & 69.7 & 22 & 73.3 \\
\hline III & 7 & 21.2 & 6 & 20.0 \\
\hline AMI in anamnesis & 29 & 88 & 27 & 90 \\
\hline CA with stenosis $>50 \%{ }^{*}$ & \multicolumn{2}{|c|}{$3.05 \pm 0.21$} & \multicolumn{2}{|c|}{$3.05 \pm 0.28$} \\
\hline Cardiopulmonary bypass time* $(\mathrm{min})$ & \multicolumn{2}{|c|}{$132.11 \pm 11.93$} & \multicolumn{2}{|c|}{$140.11 \pm 10.71$} \\
\hline Cross-clamp time* $(\min )$ & \multicolumn{2}{|c|}{$84.45 \pm 9.60$} & \multicolumn{2}{|c|}{$95.26 \pm 8.21$} \\
\hline LV plasty & 7 & 21.2 & 9 & 30.0 \\
\hline Grafts per patient* & \multicolumn{2}{|c|}{$2.90 \pm 0.23$} & \multicolumn{2}{|c|}{$2.74 \pm 0.26$} \\
\hline IABP use & 1 & 3.0 & 1 & 3.3 \\
\hline LITA graft & 31 & 94 & 28 & 93 \\
\hline RITA graft & 2 & 6.0 & 2 & 6.7 \\
\hline
\end{tabular}

Study group: patients with hypoxic preconditioning (HP); Comparison group: patients without HP; CHF: chronic heart failure; AMI: acute myocardial infarction; CA: coronary arteries; LV: left ventricle; IABP: intra-aortic balloon pump; LITA: left internal thoracic artery; RITA: right internal thoracic artery; * differences between groups are not statistically significant.

tial registration of bolus passage of the radiopharmaceutical (RP) through the compartments of the heart and lungs after its injection into the median cubital vein.

Radiocardiopulmonography was conducted in clinostatic position of a patient. The gammacamera detector was installed above the chest in the left anterior oblique projection (LAO $45^{\circ}$ ) with a caudal angle of $15^{\circ}$, in the position of the best visual "separation" of the right and left ventricles of the heart. The radiopharmaceutical was administered intravenously at a dose of 260-300 MBk (7.0-8.0 $\mathrm{mCi})$ and a volume of 1-1.5 mL. Recording was continued for $80-100$ seconds with frame frequency of 2 frames per second and 2 frames of $1 \mathrm{~min}$ to reach the plateau of RP dilution.

The result of the RCPG consists in a series of scintigrams with visualization of the aorta, heart and lungs at different time intervals. With the help of applied programs for processing scintigraphic images, the following areas of interest were identified: the right and left ventricles of the heart, and the upper lobe of the lung. Activitytime curves were plotted for each of the selected zones of interest.

The following basic hemodynamic parame- ters were calculated: cardiac minute output (MO); stroke volume (SV); blood volume in the $\mathrm{PC}$ (BVPC); heart and stroke indices (HI, SI); circulation efficiency ratio (CER); arterial modal time (TAM), which characterizes mainly blood flow in the large and small arteries, arterioles and capillaries of the lungs; venous modal time (TVM), reflecting the circulation of blood in the veins of the PC and the left heart cavities; pulmonary time (TPUL) - the sum of TAM and TVM - reflects the time of passage of the maximum amount of indicator through the lungs; ventricular half ejection times of the right ventricle $(\mathrm{T} 1 / 2 \mathrm{RV})$ and the left ventricle $(\mathrm{T} 1 / 2 \mathrm{LV})$, as indirect criteria of the contractile ability.

All scintigraphic studies were performed with gamma-camera Philips Forte (Philips Medical Systems, Netherlands). Processing of the acquired scintigrams was performed using JetStream ${ }^{\circledR}$ Workspace Release 3.0 software package (Philips Medical Systems).

Statistical analysis was performed with STATISTICA software (version 8.0.360.0.) using descriptive statistics (Descriptive statistics), nonparametric Wilcoxon rank-sum test and MannWhitney test (U test). 
Table №2. Scintigraphic parameters of cardio-pulmonary hemodynamics in patients with coronary artery disease before and after coronary artery bypass grafting.

\begin{tabular}{|c|c|c|c|c|}
\hline \multirow[t]{2}{*}{ Parameters } & \multicolumn{2}{|c|}{ Study group } & \multicolumn{2}{|c|}{ Comparison group } \\
\hline & Before CABG & $\begin{array}{l}\text { 6-8 days after } \\
\text { CABG }\end{array}$ & Before CABG & $\begin{array}{c}\text { 6-8 days after } \\
\text { CABG }\end{array}$ \\
\hline $\mathbf{T}_{\mathbf{P U L}}(\mathrm{sec})$ & $9.86 \pm 0.51$ & $\begin{array}{c}7.98 \pm 0.48 \\
p=0.001\end{array}$ & $9.19 \pm 0.51$ & $\begin{array}{c}7.43 \pm 0.42 \\
p=0.004\end{array}$ \\
\hline $\mathbf{T}_{\mathrm{AM}}(\mathrm{sec})$ & $4.59 \pm 0.24$ & $\begin{array}{c}4.19 \pm 0.24 \\
p=0.035\end{array}$ & $4.26 \pm 0.25$ & $\begin{array}{c}3.67 \pm 0.25 \\
p=0.062\end{array}$ \\
\hline $\mathbf{T}_{\text {VM }}(\sec )$ & $5.27 \pm 0.30$ & $\begin{array}{c}3.80 \pm 0.31 \\
p=0.001\end{array}$ & $4.92 \pm 0.32$ & $\begin{array}{c}3.76 \pm 0.24 \\
p=0.003\end{array}$ \\
\hline $\mathbf{T}_{\mathbf{1} / 2 \mathrm{RV}}(\mathrm{sec})$ & $3.29 \pm 0.53$ & $\begin{array}{c}2.38 \pm 0.10 \\
p=0.016\end{array}$ & $2.72 \pm 0.38$ & $\begin{array}{c}2.38 \pm 0.23 \\
p=0.328\end{array}$ \\
\hline $\mathbf{T}_{\mathbf{1} / 2 \mathrm{LV}}(\mathrm{sec})$ & $5.88 \pm 0.48$ & $\begin{array}{c}4.58 \pm 0.32 \\
p=0.009\end{array}$ & $5.29 \pm 0.37$ & $\begin{array}{c}4.80 \pm 0.32 \\
p=0.033\end{array}$ \\
\hline MO (L) & $4.23 \pm 0.27$ & $\begin{array}{c}4.97 \pm 0.28 \\
p=0.002\end{array}$ & $4.48 \pm 0.31$ & $\begin{array}{c}5.08 \pm 0.29 \\
p=0.016\end{array}$ \\
\hline $\mathbf{S V}(\mathrm{mL})$ & $65.29 \pm 3.85$ & $\begin{array}{c}68.21 \pm 3.72 \\
p=0.114\end{array}$ & $67.73 \pm 3.88$ & $\begin{array}{c}67.18 \pm 4.93 \\
p=0.610\end{array}$ \\
\hline HI $\left(\mathrm{L} / \mathrm{m}^{2}\right)$ & $2.18 \pm 0.13$ & $\begin{array}{c}2.59 \pm 0.15 \\
p=0.001\end{array}$ & $2.18 \pm 0.11$ & $\begin{array}{c}2.45 \pm 0.10 \\
p=0.008\end{array}$ \\
\hline SI $\left(\mathrm{mL} / \mathrm{m}^{2}\right)$ & $33.81 \pm 2.08$ & $\begin{array}{c}35.53 \pm 2.07 \\
p=0.099\end{array}$ & $32.96 \pm 1.08$ & $\begin{array}{c}32.74 \pm 1.70 \\
p=0.721\end{array}$ \\
\hline CER (L/min) & $0.85 \pm 0.06$ & $\begin{array}{c}1.01 \pm 0.06 \\
p=0.002\end{array}$ & $0.82 \pm 0.04$ & $\begin{array}{c}0.99 \pm 0.05 \\
\mathrm{p}=0.016\end{array}$ \\
\hline $\mathbf{B V}_{\mathbf{P C}}(\mathrm{ml})$ & $702.14 \pm 67.08$ & $\begin{array}{c}664.64 \pm 59.49 \\
p=0.056\end{array}$ & $666.18 \pm 41.30$ & $\begin{array}{c}662.95 \pm 38.87 \\
p=0.859\end{array}$ \\
\hline
\end{tabular}

Study group: patients with hypoxic preconditioning (HP); Comparison group: patients without HP; CABG: coronary artery bypass grafting; TAM: - arterial modal time; TVM: - venous modal time; TPUL: - pulmonary time (the sum of TAM and TVM); MO: cardiac minute output; SV: stroke volume; HI: heart index; SI: - ударный индекс; T1/2RV, T1/2LV: periods of ventricular half ejection; BVPC: - blood volume in the pulmonary circulation; CER: circulation efficiency ratio; p: - significance of differences in relation to the preoperative value.

\section{Results.}

Before CABG the results of the initial $\mathrm{RCPG}$ of the included in the study patients showed significant negative changes in the main parameters reflecting the functional state of cardiopulmonary hemodynamics (Table 2).

Thus, a decrease in cardiac minute volume below normal values was detected in 49 (78\%) of 63 patients, cardiac index - in 59 (94\%), stroke index - in $52(82.5 \%)$ patients and circulation efficiency ratio - in $84 \%$ cases (53 patients). The state of contractility of both the left and right ventricles of the heart can be indirectly assessed by the values of the period ventricular half ejection (T1/2RV and $\mathrm{T} 1 / 2 \mathrm{LV})$, which in patients with $\mathrm{CHF}$ were markedly increased compared with the norm (Table 2). At the same time, T1/2LV exceeded the normal value in all examined cardiac patients $(100 \%)$, and $\mathrm{T} 1 / 2 \mathrm{RV}$ - in more than half of the patients $(67 \%)$.
Table 2. Scintigraphic parameters of cardiopulmonary hemodynamics in patients with coronary artery disease before and after coronary artery bypass grafting.

Pulmonary hemodynamics in the examined patients was characterized by slowing the passage of the radiopharmaceutical from the right heart chambers to the left ones, mostly due to an increase in the minimum blood circulation time in the lungs (TPUL) and, in particular, in the arteries (TAM) (Table 2). So, prolongation of TAM was observed in the vast majority of patients (96\%); $71 \%$ of patients had an increase in TVM.

Successful myocardial revascularization in patients of both groups led to positive changes in most cardiopulmonary hemodynamics indices (increases in the mean values of MO, SI, and CER; decrease in RP pulmonary circulation; and increase in the left ventricular half ejection time) within 6-8 days after surgery (Table 2). 
Initially, before surgery, the mean values of the left ventricle ejection fraction (LVEF) (according to ultrasound) did not significantly differ between the study group (with preconditioning) and the comparison group (46.04 \pm 2.46 and $43.18 \pm$ $2.49 \%$, respectively). After CABG, there were statistically significant increases of this variable in both groups to $54.52 \pm 2.19$ and $48.73 \pm 2.31 \%$, respectively.

It should be noted that, in the study group, the positive dynamics of the majority of hemodynamic parameters (Table 2), as well as an increase in LVFF due to surgical treatment were statistically more pronounced: the significance levels (p) were 0.000013 and 0.013906 for the study group and the comparison group, respectively. The rate of patients requiring inotropic support during immediate post-perfusion and early postoperative periods was lower (by 65\%) in the group of patients who underwent HP.

In our study, the determination of the levels of creatine kinase enzymes (CK) and CK-MB - isoenzyme showed that on the day 2 after open heart surgery using EC and cardioplegia, patients of both groups had an increase in these enzymes in the blood (Table 3). Thus, there were higher than normal levels of CK (as a result of damage to skeletal muscle cells during surgery), as well as CK$\mathrm{MB}$, which serves as a marker of damage to the heart muscle. It should be noted that the average level of CK-MB was significantly higher (by 33\%) in the comparison group relative to the study group ( $p=0.046825)$ (Table 3$)$.
In our study, after surgery, the group of patients who underwent HP, in contrast to the comparison group, had a significant decrease in the right ventricular half-ejection period (T1/2RV) an indicator indirectly characterizing the contractility, as well as a decrease arterial time of the indicator circulation in the lungs (TAM), which suggesting a reduction of pulmonary hypertension and regression of right ventricular failure [19].

In 2008, German physiologists [20] found that 24-hour exposure of rats to hypoxia results in an increase in tolerance of the isolated heart to the action of ischemia-reperfusion, and is associated with improved parameters of contractility of the right ventricle.

The nature of cardiac recovery and the degree of inotropic support are among the main indicators of adequate myocardial protection after global ischemia [21]. Based on the results of hemodynamic assessment, it can be argued that HP prevents necrosis of cardiomyocytes and improves cardiac contractile function during the reperfusion period of long-term ischemia and reperfusion [15].

Determination of the activity of creatine kinase MB-isoenzyme is of great importance in the diagnosis of myocardial infarction. The average level of increased activity of CK-MB in patients with AMI is 10-25 times greater than the upper limit of the reference values.

However, researchers note that $\mathrm{CK}-\mathrm{MB}$ is not $100 \%$ specific to the myocardium, and the diagnostic value of the method is drastically reduced in cases where CK is derived from the skel-

Table №3. Indicators of enzymatic activity in patients with coronary artery disease
after coronary artery bypass surgery.

\begin{tabular}{c|c|c|c} 
Parameters & Study group & Comparison group & Norm \\
\hline CK (U/L) & $1062.21 \pm 93.82$ & $1223.52 \pm 137.91$ & $<167$ \\
\hline CK-MB (U/L) & $53.78 \pm 7.30$ & $80.72 \pm 10.51$ & $<25$ \\
\hline RI, \% & $5.46 \pm 0.54$ & $7.39 \pm 0.75$ & $<6$
\end{tabular}

Study group: patients with hypoxic preconditioning (HP); Comparison group: patients without $\mathrm{HP}$; CK: creatine kinase; CK-MB: CK isoenzyme; RI: relative index - calculated as the ratio of CK-MB to CK (in percentage).

\section{Discussion.}

The abnormalities in the majority of hemodynamic parameters of the circulatory system (MO, HI, SI and CER) suggested a decrease in the contractile ability of the heart due to the development of CHF [19]. The prolongation of TAM implied the formation of pulmonary hypertension in combination with right ventricular failure, and an increase in TVM suggested the venous overload of the left heart and adjacent large pulmonary veins, as a manifestation of the left ventricular failure [18]. etal muscle. Therefore, the determination of CK$\mathrm{MB}$ in cardiac surgery patients may increase the number of false-positive results [22].

In this regard, for an adequate assessment of damage to the myocardium, calculation of the ratio of $\mathrm{CK}-\mathrm{MB}$ concentration to a total creatine kinase activity (relative index (RI)) was introduced: RI = CK-MB / CKtot. x 100 (\%), which normally should not exceed $6 \%$. In case of myocardial damage, RI ranges from 6 to $25 \%$. As can be seen from Table 3 , the average value of RI in the study group (with preconditioning) did not ex- 
ceed $6 \%$ in contrast to the comparison group. This suggests that HP increases the tolerance of the myocardium to the damaging effects of "ischemiareperfusion", increases the resistance of vital organs to ischemic and reperfusion stress, and, consequently, reduces the number and severity of postoperative complications $[8,15]$.

Our results, indicating the cardioprotective effect of HP in patients who underwent CABG with $\mathrm{EC}$, are consistent with the data of other researchers $[8,16,17]$. Indeed, the group of Wu et al. $[16,17]$ showed that ischemic preconditioning (IP) with two 2-min episodes of global ischemia followed by 3-minute reperfusion has a significant protective effect, which manifests, in particular, as a lower concentration of troponin I in the postoperative period and high values of the left and right ventricular ejection fraction and cardiac index. Also, decreases in the frequency of supraventricular tachyarrhythmia, mechanical ventilation time, and the degree of inotropic support were observed in patients with IP. Prut D.A. et al. [23] used lactate level in blood plasma as an indirect indicator of myocardial hypoxia and anaerobic glycolysis. The blood lactate level reached the maximum values $1 \mathrm{~h}$ after removal of the aortic clamp in both

\section{References:}

1. Jones E.L., Weintraub W.S., Craver J.M., Guyton R.A., Cohen C.L. Coronary bypass surgery: is the operation different today? $J$ Thorac Cardiovasc Surg 1991; 101: 108-115.

2. Mangano D.T. Perioperative cardiac morbidity. Anesthesiology 1990; 72: 153-184.

3. Newsholm A., Start K. Metabolism regulation. Moskow, Mir, 1977. 408 p. (in Russian).

4. Hiraide T., Katsura K., Muramatsu И., Asano G., Katayama $Y$. Adenosine receptor antagonists cancelled the ischemic tolerance phenomenon in gerbil. Brain Res. 2001; 910: 1-2: 94-98.

5. Trost S. U., Omens J.H., Karlon W.J. Meyer M., Mestril R., Covell J.W., Dillmann W.H. Protection against myocardial dysfunction after a brief ischemic period in transgenic mice expressing inducible heat shock protein 70. J. Clin. Invest. 1998; 101:4:855-862.

6. Thielmann M., Kottenberg E., Boengler K., Raffelsieper C., Neuhaeuser M., Peters J., Jakob H., Heusch G. Remote ischemic preconditioning reduces myocardial injury after coronary artery bypass surgery with crystalloid cardioplegic arrest. Basic Res. Cardiol. 2010; 105: 5: 657-664.

7. Thiengburanatham S. Hyperhomocysteinemia-induced myocardial injury after coronary artery bypass. Asian Cardiovasc.Thorac. Ann. 2009; 17: 5: 483-489.

8. Maslov L.N., Lishmanov Yu.B., Emel'yanova T.V., Prut D.A., Kolar F., Portnichenko A.G. et al. Hypoxic preconditioning as a new approach to the prevention of ischemic and reperfusion injuries of the brain and heart. Angiology and Vascular Surgery. 2011; 17 (3): 27-36 (in Russian).

9. Shizukuda Y., Mallet R.T., Lee S.C., Downey H.F. Hypoxic preconditioning of ischaemic canine myocardium. Cardiovasc. Res. 1992; 26 (5): 534-542. groups of patients, however, in the group with the use of HP, the concentration of lactate in the blood was lower than in the patients of the comparison group. Consequently, HP reduces the intensity of anaerobic glycolysis in the myocardium, which can also be regarded as a positive effect of preconditioning.

Thus, the use of hypoxic preconditioning during coronary bypass surgery with extracorporeal blood circulation can reduce damage to cardiomyocytes and improve the contractile function of the heart in the reperfusion period after prolonged ischemia and reperfusion.

\section{Statement of Ethics.}

The study protocol complied with the Declaration of Helsinki and was approved by the Ethics and Research Committee of the Cardiology Research Institute, Tomsk National Research Medical Centre. All patients have given their informed written consent.

The authors declare no conflicts of interest.

Acknowledgment.

The article was prepared under the theme of fundamental scientific research № AAAA-A15115123110026-3.

10. Shizukuda Y., Iwamoto T., Mallet R.T., Downey H.F. Hypoxic preconditioning attenuates stunning caused by repeated coronary artery occlusions in dog heart. Cardiovasc. Res. 1993; 27 (4): 559-564.

11. Béguin P.C., Joyeux-Faure M., Godin-Ribuot D., Lévy P., Ribuot $C$. Acute intermittent hypoxia improves rat myocardium tolerance to ischemia. J. Appl. Physiol. 2005; 99 (3): 1064-1069. 12. Cai Z., Manalo D.J., Wei G., Rodriguez E.R., Fox-Talbot K., $L u H$. et al. Hearts from rodents exposed to intermittent hypoxia or erythropoietin are protected against ischemia-reperfusion injury. Circulation 2003; 108 (1): 79-85.

13. Wu X., Liu X., Zhu X., Tang C. Hypoxic preconditioning induces delayed cardioprotection through p38 MAPK-mediated calreticulin upregulation. Shock 2007; 27: 572-577.

14. Luk'yanova L.D., Germanova E.L., Kopaladze P.A. Regularities in the formation of organism resistance under different regimes of hypoxic preconditioning: the role of the hypoxic period and reoxygenation. Bulletin of Experimental Biology and Medicine. 2009; 147 (4): 380-384 (in Russian).

15. Maslov L.N., Lishmanov Yu.B., Krylatov A.V., Semencov A.S., Portnichenko A.G., Podoksenov Yu.K., Haliulin I.G. Comparative analysis of cardioprotective and antiarrhythmic efficacy of early and late hypoxic preconditioning. Bulletin of Experimental Biology and Medicine. 2013; 156(12): 705-708 (in Russian).

16. Wu Z.K., Iivainen T., Pehkonen E., Laurikka J., Zhang S., Tarkka M.R. Fibrillation in patients subjected to coronary artery bypass grafting. J Thorac Cardiovasc Surg. 2003; 126(5): 14771482.

17. Wu Z.K., Pehkonen E., Laurikka J., Kaukinen L., Honkonen E.L., Kaukinen S. Et al. The protective effects of preconditioning decline in aged patients undergoing coronary artery bypass 


\section{RUSSIAN ELECTRONIC JOURNAL OF RADIOLOGY}

grafting. J Thorac Cardiovasc Surg. 2001; 122(5): 972-978.

18. Sivachenko T.P., Belous A.K., Zozulya A.A. Radiocardiography. Kiev. Zdorov'ya. 1984. 144 p. (in Russian).

19. Lishmanov Yu.B., Krivonogov N.G., Zavadovsky K.V. Radionuclide diagnostics of the pathology of pulmonary circulation.Tomsk. STT. 2007. 180 p. (in Russian).

20. Wasserfuhr D., Cetin S.M., Yang J., Freitag P., Frede S., Jakob H., Massoudy P. Protection of the right ventricle from ischemia and reperfusion by preceding hypoxia. NaunynSchmiedeberg's Arch. Pharmacol. 2008; 378: 27-32.

21. Guide to cardiac anesthesiology. Trekova N.A., Bunyatyan A.A. (edd). Moskow. Medical Information Agency. 2005. 688 p. (in Russian).

22. Osipova O.A., Suyazova S.B., Vlasenko M.A., Godlevskaya O.M. Diagnosis of intraoperative myocardial infarction during surgical revascularization. Modern problems of science and education 2012; 3. Available at: www.science-education.ru/1036276.

23. Prut D.A., Emel'yanova T.V., Kiyko O.G., Podoksenov Yu.K. Ischemic preconditioning as a factor in myocardial protection during cardiac surgery. Siberian Medical Journal (Tomsk) 2009; 1 (ed. 1): 120 (in Russian). 